\section{Dansk lærebok i psykiatri}

Mors O, Kragh-Sørensen P, Parnas J, red. Klinisk psykiatri

3. utg. 700 s, tab, ill. København: Munksgaard Danmark, 2009. Pris DKK 698

ISBN 978-87-628-0579-8

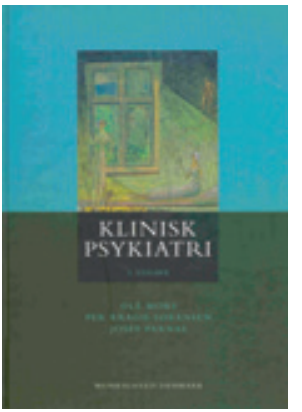

Dette er en lærebok beregnet på leger i grunn- og videreutdanning og andre helsearbeidere. Den kan også brukes som oppslagsverk av praktiserende leger. Det er bidrag fra mange forfattere, hvorav én

norsk - professor Alv A. Dahl, som har skrevet kapitlet om personlighetsforstyrrelser. De 15 kapitlene dekker temaer som psykiatriens teoretiske fundament, sykdomsbegreper, klassifikasjon/diagnostikk og epidemiologi samt de ulike psykiske lidelsene basert på ICD-10-diagnostikk. Et kapittel omhandler transkulturell psykiatri, ett er viet temaet bevissthet og ett handler om psykiatrisk genetikk.

Layouten er kompakt, uten bilder. Det kliniske stoffet er illustrert ved kasuistikker. Kapitlene om psykiatrisk epidemiologi og psykiatrisk genetikk er tematisk nær knyttet til hverandre, men plassert svært langt fra hverandre. Det er noe ulogisk i hvordan stoffet er delt mellom de to kapitlene. Familiestudier er en epidemiologisk metode, men blir presentert i kapitlet om genetikk. Hovedvekten er lagt på deskriptiv epidemiologi (de ulike lidelsers forekomst). Epidemiologi som årsaksforskning kunne vært beskrevet tydeligere.

Innledningsvis presenteres psykiatri som en naturvitenskapelig disiplin, et syn som gjennomsyrer hele boken. I denne siste utgaven er det tatt inn to nye kapitlerOm psykiatriens teoretiske fundament og Bevissthet. I sistnevnte presenteres bevissthetsfilosofi, med en innføring i bl.a. fenomenologi. Disse to kapitlene blir stående litt for seg selv. Kun i kapitlet om schizofreni er teorier/begreper fra bevissthetsfilosofien trukket inn i beskrivelsen av symptomatologi/klinisk bilde slik at de gir et vesentlig bidrag. Beskrivelsen av symptomer/klinisk bilde ved lidelsene i det schizofrene spektrum er svært lang 52 sider. Kapitlet om bevissthetsfilosofi kan trolig bli noe tungt på dansk for dem som ikke har filosofi i grunnutdanningen.

Kapitlet om belastningsrelaterte, dissosiative og somatoforme lidelser er nyskrevet, og vil kunne være svært nyttig for allmennpraktikere.

Jeg savner stoff om ukuelighet (resilience), mestring/mestringsstrategier. En ordliste med definisjoner av de vanligste ord og begreper hadde gjort stoffet mer tilgjengelig for dem som ikke arbeider i psykiatrien til daglig.

For øvrig er Klinisk psykiatri grundig og omfattende. Det vil ikke være noen stor vanskelighet for de fleste nordmenn å lese en lærebok på dansk, og dansk psykiatri er ganske lik norsk når det gjelder forståelsesperspektiver og valg av behandling. På noen felter er det nok noen mindre forskjeller, og norske lesere bør derfor konsultere norske behandlingsretningslinjer der slike finnes. I tillegg vil lovverket når det gjelder bruk av tvang, hvilke legemidler som fås på blåresept osv. være noe forskjellig, slik at også her vil man måtte bruke supplerende litteratur om regelverket i Norge. Klinisk psykiatri kan anbefales som et alternativ til norske lærebøker for de aktuelle målgruppene.

\section{Reidun E. Olstad}

Psykiatrisk forskning

Fag- og forskningssenter

Universitetssykehuset Nord-Norge

\section{Ny og forbedret}

Markestad T.

\section{Klinisk pediatri}

2. utg. 416 s, tab, ill. Bergen: Fagbokforlaget,

2009. Pris NOK 478

ISBN 978-82-450-0745-9

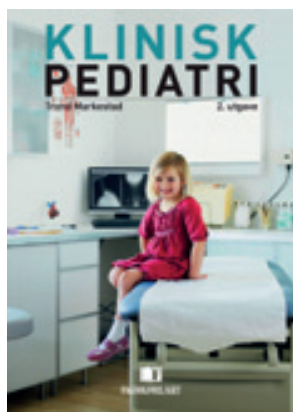

Første utgave av denne læreboken kom i 2003. Den nye er betydelig omarbeidet, utvidet og oppdatert.

Det første som slår meg er omslaget, som i motsetning til omslaget på den forrige utgaven er innbydende og umiddelbart vekker leselyst. At barneleger med spesialkompetanse har vært medforfattere på en rekke kapitler, har ført til at dette er blitt en svært forbedret versjon.

Klinisk pediatri er ifølge hovedforfatteren beregnet for legestudenter, leger, sykepleiere innen videreutdanning i barnesykepleie, helsesøstre og annet helsepersonell som særlig arbeider med barn. Dette gjenspeiler seg da også i innholdet. Det er klare og definerte kapitler. Den første delen omhandler grunnleggende kunnskap om pediatri, de resterende kapitlene omhandler ulike organsystemer. Dette gjør det enkelt å slå opp og se helheten i problemer man ønsker å vite mer om. Språket er lett, med en bra balanse av medisinske uttrykk og allment vokabular. Boken er oversiktlig, noe som gjør det enkelt å finne frem til essensen av innholdet. I tillegg er særlig viktig informasjon fremhevet i rammer og tabeller i rødt. Denne utgaven inneholder også flere bilder enn førsteutgaven, men den kunne godt ha hatt enda flere, som supplement til teksten.

Det er en del flytskjemaer, noe som gjør bruken som oppslagsverk i en klinisk hverdag enkel. Dette er i samsvar med forfatterens intensjoner - Klinisk pediatri skal være til hjelp ved en systematisk differensialdiagnostikk av et sykt barn.

Den inneholder også oversiktlige tabeller for medikamentell behandling ved aktuelle akutte og kroniske problemstillinger, for eksempel status epilepticus og eksem. Tabellene med anatomiske, fysiologiske og biokjemiske normalverdier er også svært nyttige.

Denne utgivelsen fremstår som en totalt revidert versjon av førsteutgaven. Dette er i samsvar med forfatterens intensjoner. Den vil være av interesse for alle som er opptatt av aktuelle utfordringer innen pediatri, kan fungere som en god pensumbok for medisinstudenter og være nyttig for ferske leger under spesialisering i barnesykdommer. Den bør brukes av mange som har med syke barn å gjøre.

\section{Christian Siva}

Barnesenteret

Oslo universitetssykehus, Ullevål

\section{Grundig om tilknytning}

Wilkinson S. Lidelse og lindring

Tilknytning og sykdomsspråk. 329 s, ill. Oslo: Gyldendal Akademisk, 2008. Pris NOK 375 ISBN 978-82-05-34333-7

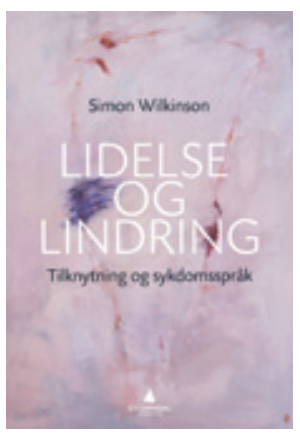

Simon Wilkinson henvender seg til «alle som møter pasienter i sitt arbeid, i første rekke psykologer og leger». Han tar utgangspunkt i det syke mennesket, eksemplifisert gjennom «Ida» og hennes tanker, følelser og atferd i forhold til en astmalidelse og etter hvert gjennom flere av livets utfordringer. Vi følger henne og hennes mor. Hennes møte med helsevesenet, særlig legestanden, beskrives også.

Wilkinson anvender tilknytningsteori som gjennomgående forståelsesmodell for menneskers sykdomsatferd og møte med sine hjelpere. Lidelse og lindring er bygd opp som en lærebok der vi får en presentasjon av tilknytningsteorien som modell.

Teorien brukes for å belyse hvordan ulike 
typer tilknytningsatferd utløses hos det syke eller sykdomstruede menneske, hos omsorgsgivere og andre nære pårørende og hos hjelperne i helsevesenet.

I de første kapitlene får vi en gjennomgang av begreper som «sykdom», «symptomer» og «lidelse». Vi føres inn i begreper som det engelske språket er så mye rikere på enn vårt eget: «illness», «sickness», «disease» og «disorder», nyanser som alle som arbeider med «sykdom» bør ha et reflektert forhold til.

I kapittel 2 og kapittel 3 gis en grundig innføring i den nevrobiologiske basis for hjernens utvikling, sett lys av kunnskaper om genetikk, nevrobiologi og anatomi og hjernens vekst og utvikling. Wilkinson er innom et bredt felt av ny viten om hukommelse og læring, temperamentsfaktorer og emosjonell og sosial utvikling. Han vender hele tiden tilbake til tilknytningsteorien som det bærende element i sin modell, en modell han har utviklet i samarbeid med Pat Crittenden.

Videre går Wilkinson i tre nye kapitler gjennom sykdomsspråket og det han mener er typisk atferd hos mennesker som gjør bruk av de ulike tilknytningsstrategiene den balanserte, trygge (type B), den forbeholdne (type A) og den «selvopptatte» (type C). Modellen brukes til å vise hvordan tilknytningsmønsteret får konsekvenser for sykdomsspråket. Tilknytningsatferden (på godt og vondt) preger oppfatningen av sykdommen og relasjonen til de tilgjengelige hjelperne. Konstruktive, men også destruktive mestringsstrategier tas i bruk. I teksten utviskes forskjellene mellom «psykiatrisk» og «somatisk» helsevesen. Tilknytningsstrategiene er i bruk både «på kirurgen»

og «på psykiatrisk» (og slett ikke bare hos fastlegen).

Vår rolle som hjelpere reflekteres også. Vi har alle våre tilknytningsmønstre som spiller seg ut i disse møtene. De siste kapitlene er viet nettopp dette, først i forhold til de «tvetydige symptomene» og betydningen av vår holdning og rolle. Pasienten trenger å bli møtt av en lege med en atferd som «tunes inn» i forhold til hennes mønster. Det handler blant annet om å finne balansen mellom følelser og rasjonale i et «måljustert felleskap».

Med henvisning til Bowlby mener forfatteren at «vellykket behandling, uansett om det dreier seg om psykiatri eller indremedisin, er avhengig av at pasienten har en trygg nok base». «Cure» og «care» henger tett sammen. Gjennom tilknytningsteori tilbyr Wilkinson oss en måte å forstå forbindelsen på. Gjennom å bli oss mer bevisst våre egne tilknytningsmønstre kan vi hjelpe pasientene bedre. Det er et verktøy for å redusere dysfunksjonelle samhandlingsmønstre i lege-pasient-forholdet.

Dette er en tekst som krever sin leser. Den er spekket med informasjon. Her er henvisninger til ulike forståelsesmodeller, som underbygges med referanser. Referanseliste og stikkordliste er tilgjengelig for den som vil trenge videre inn i stoffet. Figurer og bokser med tabeller og oversikter hjelper leseren underveis. «Ida» og beskrivelsene av hennes vei gjennom forskjellige utviklingsstadier er til hjelp for leseren når det gjelder å forstå og følge resonnementet. Dessverre er boken preget av et nokså tungt språk med lange setninger. Grundigheten går en del steder på bekostning av tilgjengeligheten.

Likevel: Jeg anbefaler Lidelse og lindring til alle som ønsker en teoretisk tilnærming til temaet. Hold ut gjennom et litt tungt akademisk språk til siste kapittel. Der kommer det praktiske råd og kloke leveregler! Et «måljustert fellesskap for helse» kan pasientene og vi jammen trenge. Wilkinson trekker opp en viktig vei for pasientbehandler-relasjonene i vårt moderne helsevesen, som er preget av teknologiske nyvinninger og stort pengeforbruk på den ene side og av forventningskrise på den annen.

\section{Ida Garløv}

Barne- og ungdomspsykiatrisk avdeling

Stavanger universitetssykehus

\section{Narkotikadebatt i svensk perspektiv}

Johansson E, Laanemets L, Svensson K, red. Narkotikamissbruk

Debatt, behandling och begrepp. $186 \mathrm{~s}$. Lund: Studentlitteratur, 2009. Pris SEK 223 ISBN 978-91-44-05212-0

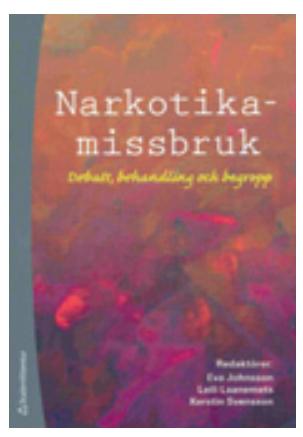

Økningen i bruken av illegale rusmidler er et betydelig sosialt og helsemessig problem i de fleste land. Debatten har ofte vært intensiv, ikke minst i Sverige. Dette er en artikkelsamling som sikter mot

å belyse og avklare prinsipper og sentrale begreper. Det er ett kapittel om viktige aktører i utviklingen av svensk narkotikapolitikk, ett om misbruksutvikling som karriere, ett om narrativ forståelse av misbrukende kvinner, ett om språk og sjargong i rusmiljøene, ett om motivasjonsarbeid og ett om tilbakefall og tilbakefallsforebygging. Kapitlet Att knarka eller inte knarka belyser misbruk i et sosiokulturelt perspektiv og kontrollproblemene i legemiddelassistert rehabilitering (LAR) på grunnlag av empirisk forskning. Avslutningskapitlet binder sammen en del av temaene ut fra en forståelse av misbruk som sosialt problem og sosialt arbeid som problemløsning.

Forfatterne av de ulike kapitlene er lærere og forskere ved svenske universiteter og høyskoler med sosiale utdanninger. Boken preges noe av at bidragene er innspill i en debatt som norske lesere ikke nødvendigvis kjenner seg igjen i, men de fleste kapitlene er dyptpløyende og gir gode analyser av sentrale spørsmål. Narkotikamissbruk kan derfor være interessant for dem som er opptatt av utviklingen i svensk narkotikapolitikk og svenske retningslinjer. Den kan også være interessant for dem som ønsker å trenge inn i en sosial forståelse av misbruksutvikling og få nyansert innsikt i muligheter og begrensninger ved sosialt arbeid.

\section{Helge Waal}

Senter for rus og avhengighetsforskning (SERAF) Institutt for psykiatri

Universitetet i Oslo

\section{Ikke så tilfeldig likevel?}

\section{Stams $\varnothing$ MA, red Velferdsstaten i endring}

Norsk sosialpolitikk ved starten av et nytt århundre. 2. utg. 354 s, tab, ill. Oslo: Gyldendal Akademisk, 2009. Pris NOK 450 ISBN 978-82-05-39360-8

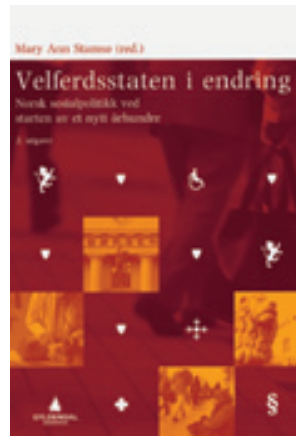

Dette er annenutgaven av en lærebok i helseog sosialpolitikk for studenter. Den består av 12 selvstendige kapitler av seks forfattere som til sammen dekker et tverrfaglig spekter fra sosialmedisin via sosiologi til sam-

funnsøkonomi. Alle kapitlene er skåret over samme pedagogiske lest. De avrundes med et oppsummeringsavsnitt, oppgaver til diskusjon og litteraturliste.

Dette er ikke noe man leser fra perm til perm for fornøyelsens skyld. Men det går an å slå opp. Via kapitteloverskrifter og et ryddig stikkordregister finner man omtaler av de aller fleste av velferdsstatens lover, institusjoner og begreper. Teksten dekker med andre ord mange temaer, den blir til gjengjeld mye preget av oppramsing på bekostning av dybde.

Siden man har fått med så mye, burde også forholdet mellom sosialpolitikken og arbeidsmarkedet vært behandlet. Den generelle betydningen av arbeidervernlovgiving er for eksempel glemt, selv om arbeiderkommisjonen av 1885 er omtalt. I motset- 